\title{
A Literary and Cultural Stare of the Red Thread Eka Kurniawan
}

\author{
Herdi Sahrasad ${ }^{1}$, Muhammad Ridwan ${ }^{2}$ \\ ${ }^{1}$ Universitas Paramadina, Indonesia \\ ${ }^{2}$ Universitas Islam Negeri Sumatera Utara (UINSU), Medan, Indonesia \\ bukharyahmedal@gmail.com
}

\begin{abstract}
This study is a literary and cultural stare of the red thread Eka Kurniawan. As a young writer, Eka Kurniawan successfully spawned three novels that brought her name increasingly known in international literature. His works are also considered capable of inheriting a 'moving' literary tradition, in which the literary notions of socialist realism are echoed. As a results the language of Eka in Beauty, an elegant wound, and the wealth of his imagination provided excitement, like joy when he saw the snow falling for the first time. Ben Anderson even mentioned Eka as Pramoedya's replacement. He also mentioned Eka as the novel writer and the most original short story in Indonesia. Eka claimed to imitate Pram's discipline in making story details. Eka's comment? "I'm still far from Pram," Eka said in response to her comparison with Pramoedya. But it was precisely there that was the challenge for Eka to continue working as Ben Anderson and Pramudya had hoped for him.
\end{abstract}

Keywords: red thread; Ben Anderson; Pramudya Ananta Toer; literary and cultural stare

\section{Introduction}

Eka Kurniawan, a young Sundanese writer who has published two amazing novels in the past half-decade. With a touching metaphor, Ben Anderson considers Eka's presence in modern Indonesian literature to give a shadow of prospects and times by saying that if someone considers the plot and character in the novels to be often terrible, it can be said to be hopeless. But the beauty and elegance of their language, and the excitement of their imagination, gave one the joy of watching the first snowdrops extend their little heads towards the winter sky

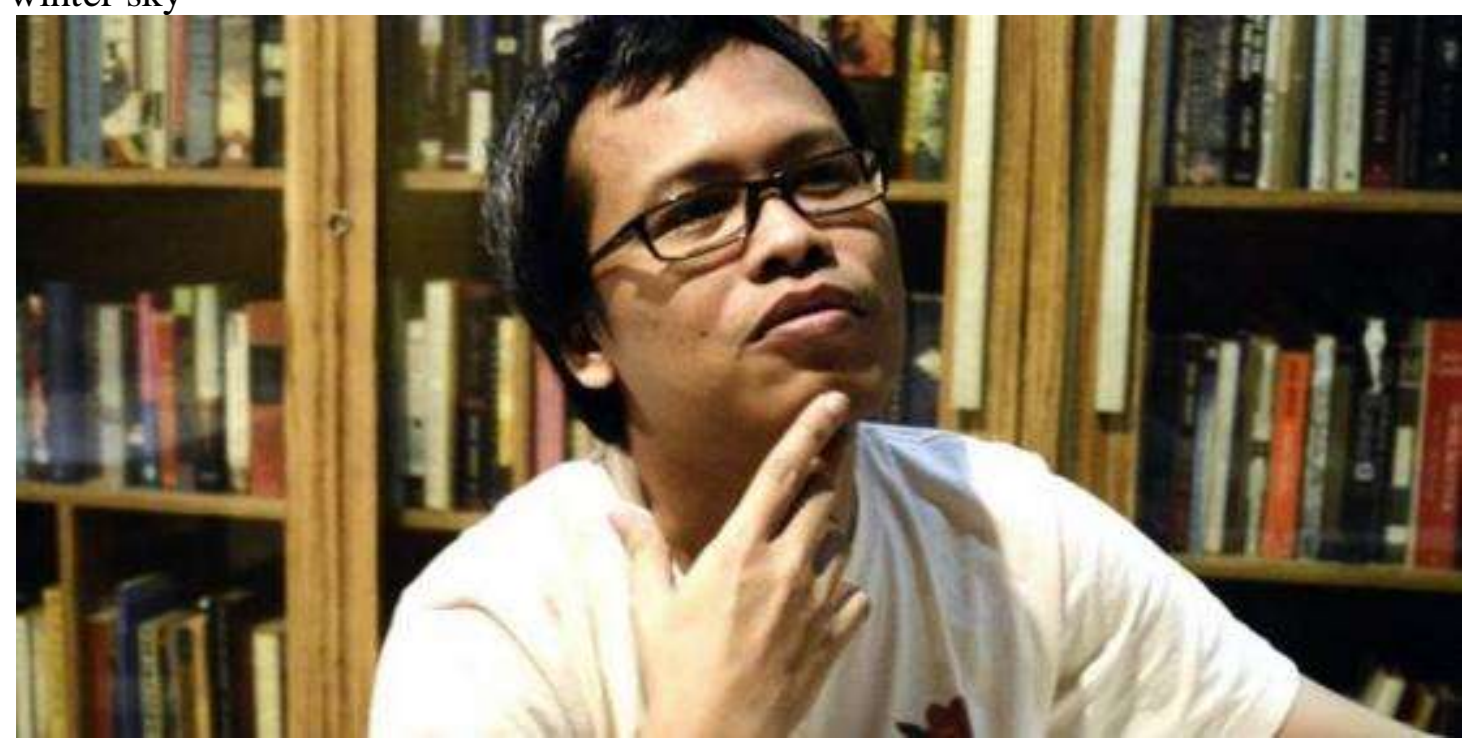

Eka Kurniawan | GOH CHAI HIN / AFP 
Konfrontasi Journal: Culture, Economy and Social Changes, 6 (2) July 2019, 18-30

P-ISSN: 1410-881X (Print)

Herdi Sahrasad, Muhammad Ridwan: A Literary and Cultural Stare of the Red Thread Eka Kurniawan

DOI: -

http://www.konfrontasi.net/index.php/konfrontasi2

Even in the footnote to Ben Anderson's essay on the Apr. 2008 New Left Review, Ben stressed clearly that Eka was a great admirer of Pramoedya, writing a first-class academic thesis at the UGM Faculty of Philosophy in Yogyakarta and already published. The thesis is about the complex relationship of older writers with 'Socialist Realism'. Eka's two novels are Cantik Itu Luka [Beauty is A Wound, 2002) and Lelaki Harimau [Man Tiger, 2004) is also very appreciated by Ben Anderson. The first novel is a large, rather difficult recapitulation, surreal of the last century of Indonesian history described in Macondo, an isolated place on the south coast of Java. The second novel is a village tragedy that is brilliantly written, intimately intertwined and frightening, also happening somewhere in the barren coast. Both novels have been translated into English (other languages).

'Eka, a great admirer of Pramoedya, wrote a first-class academic thesis, since published, on the older writer's complex relationship with 'socialist realism'. The two novels are Cantik Itu Luka ['Beauty is A Wound, 2002) and Lelaki Harimau [Man Tiger, 2004). The first is a huge, rather unwieldy, surreal recapitulation of the past century of Indonesian history set in a sort of isolated Macondo somewhere on the south coast of Java. The second is a brilliant, tight-knit and frightening village tragedy, also set somewhere on that barren littoral. I understand that both novels are starting to be translated into other languages.'

In this connection, Benedict Richard O'Gorman Anderson praised the language of Eka in Beauty is A Wound as an elegant novel and the wealth of his imagination provided excitement, like joy when he saw the snow falling for the first time. Ben Anderson even mentioned Eka as Pramoedya's successor. He also mentioned Eka as the promising writer and the most original short story author in Indonesia. Eka claimed to imitate Pram's discipline in making story details. "I'm still far from Pram," said Eka humbly responding to her comparison with Pramoedya.

TM Lutfi Yazid SH LLM, Prof Benedict Anderson dan Dr Herdi Sahrasad in the corner of the park at Cornell University, Ithaca, New York, autumn 1994 (Picture by Drs Saefudin Simon MSE)

Eka Kurniawan knew Prof. Benedict Anderson starting in 2008, while he is still living in an apartment in Benhil (Bendungan Hilir), not yet in Ciputat, Tangerang Selatan. 'Since 2008, every time Ben goes to Indonesia, we always meet,' 'said Eka. It all started from Ben Anderson's question to several students in Yogya, about who was a good Indonesian writer. They (students) then recommend my book, like Beauty is A Wound, Man Tiger and Scribble on the Toilet. Ben Anderson then took the novels to Cornell (University). Since then, Ben Anderson has always asked to meet himself when going to Indonesia. Ben Anderson paved the way for Eka to publishers in the UK, Verso Books UK.

According to Eka, it was Ben Anderson who recommended the publisher from the beginning of the meeting. He also kept telling me to translate Eka's novel. Every time you meet, always repeat the same thing. Until finally, in 2011, Ben Anderson decided on Tariq Ali, a novelist, who was also an activist, to come to Indonesia to persuade me to publish books in English. Finally the translation was done, "Ben Anderson and I chose to choose the Dalih (Labodalih Sembiring) to translate the Tiger Man into English. At first Ben and I were a little confused translating Man Tiger, because the translation was rather strange, becoming Tiger Man. Finally we agreed to call it Man Tiger, " Eka said in an interview.

Novel Beauty is Wound won the World Readers Awards which was held on Tuesday (03/22/2016) in Hong Kong. The awarding was also given to the novel's translator, Annie 
Konfrontasi Journal: Culture, Economy and Social Changes, 6 (2) July 2019, 18-30

P-ISSN: 1410-881X (Print)

Herdi Sahrasad, Muhammad Ridwan: A Literary and Cultural Stare of the Red Thread Eka Kurniawan

DOI: -

http://www.konfrontasi.net/index.php/konfrontasi2

Tucker, who considered the Eka novel fresh and new to the reader. The Man Tiger or Man Tiger is nominated at Man Booker Prize 2016, which is a prestigious award for English literature. Eka's name is lined with well-known writers, such as Orhan Pamuk (Turkey), Han Kang (South Korea), Yan Lianke (China) or Kenzaburo (Japan).

From Eka Kurniawan's own confession, in fact, Ben Anderson, the professor at Cornell University, was the first to urge Eka to translate her novels. Now the Beauty is Wound been translated into 24 languages and Lelaki Harimau translated in 5 languages. Eka Kurniawan is a young writer who respects and admires as well as great recognition for the achievements of Pramudya Ananta Toer in the world of Indonesian literature and culture. Like Pram, besides writing novels / prose, Eka also writes essays and reports. Eka completed her studies at UGM in 1999, with a thesis entitled Pramoedya Ananta Toer dan Sastra Realisme Sosialis (Pramoedya Ananta Toer and Socialist Realism Literature), which was also published as a book that attracted many readers.

As a young writer, Eka Kurniawan successfully spawned three novels that brought her name increasingly known in international literature. His works are also considered capable of inheriting a 'moving' literary tradition, in which the literary notions of socialist realism are echoed.

But did you know that for him to be a writer it hurts?

Perhaps the view of literary critics and literary researchers is true that when reading Eka's work, neither happy nor sad feelings appear. "It is not enough for me to say this is a tragedy, one example of which is an absurd tragedy. How does this absurdity produce something ridiculous and funny," said Saras Dewi, a Lecturer in Philosophy at the University of Indonesia, Dr. Saras Dewi at Erasmus Huis Jakarta. The work of Eka Kurniawan, a writer from the Sundanese landscape, was able to enter on the map of Indonesian literature. The books written by the young man from Tasikmalaya brought his name in line with other world writers.

However, Eka does not want to be called the successor of Pramoedya Ananta Toer, although he cannot avoid his influence. "But I can't deny that Pram has an influence on my writing. I try to free myself from Pram but there are certain things that cannot be avoided," Eka said, telling the writing process at Erasmus Huis Jakarta. If asked what is the most influential of Pram's figure toward his writer's gait? The novelist 'O' emphatically will answer is the enthusiasm of Pram to write and free to see Indonesia from his side. "I tried to move away, I tried to criticize maybe Pram would be better for this. When I saw Indonesia, I saw more from Pram," Eka said.

Eka admitted that she continued to study literature, which perhaps if Pram was still alive, he would read it all too. Eka also reads forgotten or neglected works. At the end of December 2018, the author of 'Seperti Dendam Rindu Harus Dibayar Tuntas' ( 'Like Longing for Revenge Must Be Paid Completely' received the Prince Claus award from the Kingdom of the Netherlands. He got the award for his achievements in developing culture in the literary category.

In terms of character and development is now more developed. If we look, it appears that the works of Eka Kurniawan describe the condition of Indonesia, for example there were incidents of the 1965 massacre, and his works inherited the literary tradition of 'moving' Even literature, still a source of history to understand what was silenced. Eka Kurniawan received 2018 Prince Claus Awards from the Kingdom of the Netherlands. Through his books, Eka is 
Konfrontasi Journal: Culture, Economy and Social Changes, 6 (2) July 2019, 18-30

P-ISSN: 1410-881X (Print)

Herdi Sahrasad, Muhammad Ridwan: A Literary and Cultural Stare of the Red Thread Eka Kurniawan

DOI: -

http://www.konfrontasi.net/index.php/konfrontasi2

able to develop Indonesian culture in the literary category and introduce it to international readers.

In producing his work, Eka claimed to learn from Pramoedya Ananta Toer's works and finally found her own style. Graduates of Philosophy at the University of Gadjah Mada (UGM) often combine elements of tradition, word of mouth, pencak silat, until horror comics are used to describe a very layered community experience. No wonder if these unique works are often equated with writer Gabriel Garcia Marquez and Haruki Murakami. One of his novels, 'Beautiful is Wound' in 2002 was also translated into 34 languages.

\section{Review of Literature}

Eka Kurniawan was born in a village, two hours from Tasikmalaya, November 28, 1975 and lived there with her four grandparents. It was the village that was the starting point for 'O Dogs'. Several other materials were obtained from other places, he followed his parents to live on rubber plantations in Cilacap, before they moved again to the small town of Pangandaran.

In that city, precisely when entering Pangandaran 1 Junior High School, Eka Kurniawan's desire first appeared to write. Perhaps it is driven by its introduction to reading books that are rented out by reading parks that drive around on bicycles. His first poem appeared in the Sahabat children's magazine. He also wrote funny short stories for his friends to read.

His school continued to SMAN 1 Tasikmalaya and stayed with his aunt. There he was more in the school library, wrote at home (his father gave him a portable typewriter because he managed to get the top five graduates) until he felt bored. He began his journey for weeks across cities to Jakarta, then turned east through Cirebon, Tegal and Purwokerto.

Really, Eka who is still a teenager has tried to live on the road. This is his confession ", When I was in high school I lived in my aunt's house. First grade second semester, I never went to school, never entered. My aunt thinks that I went home to my parents' house. My parents thought I was still at my aunt's house. Yes, those days did not have cellphones yet, haven't asked questions. Everything is prejudiced against me, ".

" I'm not aware, three months passed when I was found. I have gone to the shore. It's already gone to Pangandaran, and it's not back home. Found by one of my uncles and told to go home. When I got home, it was discovered that I had been expelled from school. There is a letter, given two choices, this will be issued because blah-blah-blah or want to enter again, but first class again. Wow, I'm lazy if in the first grade again, the longer I go to school. I said, just released it. Finally I don't go to school for how long. When my friend is in second grade, now I'm still not going to school, but it's already at home. " Eka said.

" It's boring at home too. There are no friends, from morning to afternoon there is no one like that. I told my mother, if there is a school that wants to accept me in the second grade, I can go to school. My father is looking for me, coincidentally, my father knows many schools because he sometimes helps some schools to teach English, " he said.

" There is one school that I then enter. When I entered, there was only 13 classes. And maybe half of the waste from other schools too. There are those who never go to school, continue to be issued. Some are pregnant out of wedlock, go in there. He also brojolin his son used to go to school again. Yes it's like that. Because the contents are like that, the school is 
Konfrontasi Journal: Culture, Economy and Social Changes, 6 (2) July 2019, 18-30

P-ISSN: 1410-881X (Print)

Herdi Sahrasad, Muhammad Ridwan: A Literary and Cultural Stare of the Red Thread Eka Kurniawan

DOI: -

http://www.konfrontasi.net/index.php/konfrontasi2

very fun for me. Entering the first lesson, the second lesson was exhausted, yes, I already went to the canteen until the lesson, entered again. The teacher doesn't really care, " Eka tells.

When he returned, the school had issued it. Issued from SMA Negeri 1 Tasikmalaya, Eka then sent her father to the Islamic boarding school. Eka, who was not at ease, chose to run away shortly afterwards. "What do you want now?"

Not only asking, Eka Kurniawan's parents also showed a letter from Eka's school stating that his son had been expelled for truant for three months. "I replied," I don't want to go to school. "That's all," Eka said to her confused mothers. He then laughed when he told me about his mischief when he was a teenager.

Eka, of course, was sought after by her anxious parents. When he finally returned home, there was no angry tone from the voice of Eka's parents. But he knew his mothers were disappointed because he was expelled from school. Eka has also been sentenced by Guidance and Counseling (BP) teachers. Because of the problem, he was discovered reading the Enny Arrow Stencils novel.

At that time Eka was still in the first grade of high school. He felt so bored that he had to go to class and listen to his teacher teach. Eka is a teenager, who is crazy about the adventure series of Old Shatterhand by Karl May and Balada Si Roy, written by Gola Gong, feeling it needs adventure. Tasikmalaya, where he was born and raised, is too small and boring. He is saturated every day just going to school, then playing soccer or playing on Pangandaran Beach.

Without telling his parents, Eka traveled to a number of cities and did not return home for three months. "It's not far away, from Tasikmalaya going east to Jogja, Purwokerto, Jogja, Malang, turning back, going north to Jakarta, continuing back to Tasik, to Pangandaran," Eka said when met by reporters detikX.

Enny Arrow books are usually sold clandestinely among stacks of crossword books circulated by hawkers on the bus. "

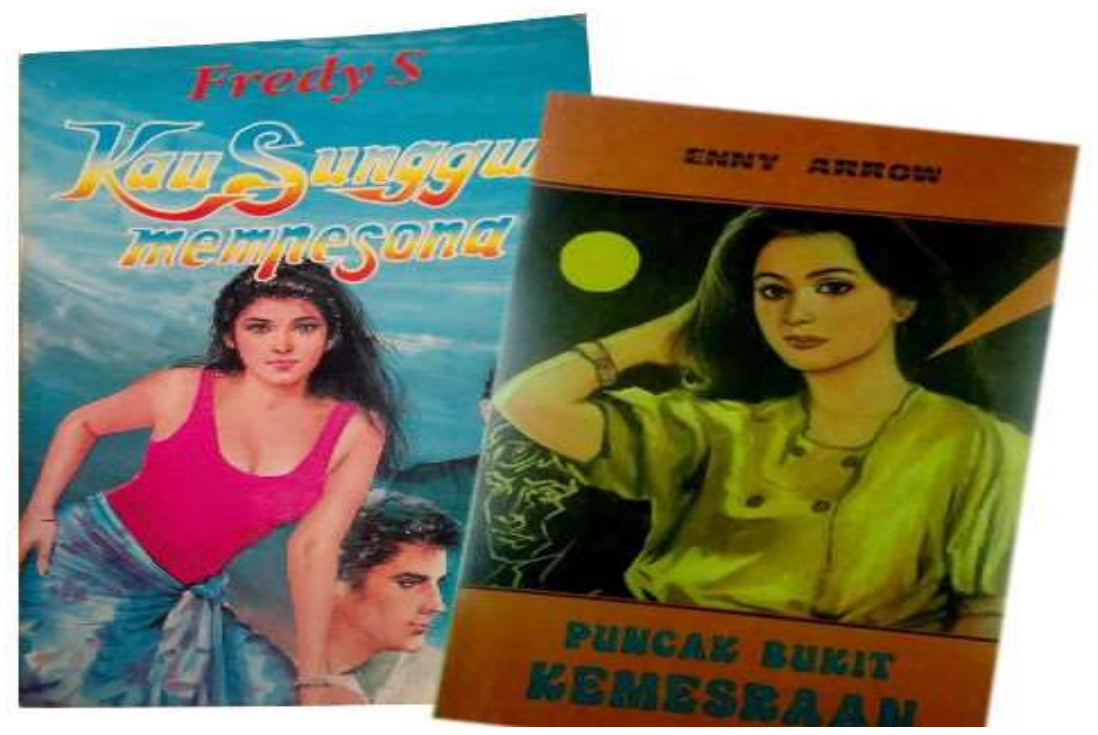

Novel Fredy S. dan Enny Arrow

Picture: Istimewa 
Konfrontasi Journal: Culture, Economy and Social Changes, 6 (2) July 2019, 18-30

P-ISSN: 1410-881X (Print)

Herdi Sahrasad, Muhammad Ridwan: A Literary and Cultural Stare of the Red Thread Eka Kurniawan

DOI: -

http://www.konfrontasi.net/index.php/konfrontasi2

Eka is hooked and likes to read. But Pangandaran, the city where he lived and attended school, in the 1980s did not have a bookstore and there was also no library. Little Eka until teenagers have never seen Indonesian literary canons, like the novel Y.B. Mangunwijaya, Ahmad Tohari, or Umar Kayam. The book that can be obtained by Eka is only "sloppy" novels, which generally circulate in the area. Asmaraman S. Kho Ping Hoo, Fredy S., Abdullah Harahap, Bastian Tito, and the Enny Arrow stencils book which of course became forbidden reading in schools. As a distraction, he read Enid Blyton and Karl May. "Yes, reading Enny Arrow is like other teenagers, ha-ha-ha ... It's a pity if you don't read it, ha-ha-ha ..., "said the writer's husband, Ratih Kumala.

Eka, the man who was born on November 28, 1975 told me, during his adolescence, Enny Arrow books were usually sold clandestinely among stacks of crossword puzzles (TTS) which were circulated by hawkers on the bus. Eka usually gets a book containing pornographic stories from the seller's subscription. The price at that time, in the 1980s, was quite expensive: Rp. 500. While the pocket money that Eka had as a junior high school student was only Rp. 100. "But usually we junior high school students had one book that they bought themselves. After that, just change it, on the screen. Tuker-tuk, "he said. To read it, Eka never dared to do it at home, afraid of being found by parents. She read it at school during recess. "Never been caught, taken to BP's teacher because of that, ha-ha ..." For Eka, reading the Enny Arrow stenciled novel was not something to be ashamed of. One generation of writers with him almost all read Enny's novels. "I read like the middle school high school. I read because I'm happy. At that time, there was no critical power, "he said. ("'Later, when he became an adult and became a famous writer, half made fun of satire Eka wrote about Enny on his blog with the title "Imagining the Enny Arrow as a Milestone in Indonesian Literature.")

"' Is it affected by Enny Arrow, yes I don't know. Maybe. Ah, but I don't know. What is clear is that everything I read is of course embedded in my head, "Eka said.

In the novel Cantik Itu Luka(Beauty is A Wound), with the main character Dewi Ayu as a prostitute, Eka reluctantly shakes up the love scene, even incest love, naughtyly. Against critics who say his writing is too vulgar, Eka said, it was impossible for sexual relations to be carried out with courtesy. "Is it affected by Enny Arrow, yeah I don't know. Maybe. Ah, but I don't know. What is clear, everything I read is of course embedded in my head, "said this petite man.

For Eka, sloppy (picisan) literature gave important meaning not only in his work, but also in his life. Without such sloppy literature, he felt he would undergo a boring adolescence.

\section{Discussion}

Beauty is A Wound has now been translated in 34 languages. Aside from being pretty wounded, Eka published Corat-coret di Toilet (Scribbling on the Toilet, 2000), Lelaki Harimau (Man Tiger, 2004), Gelak Sedih dan Cerita-cerita Lainnya (Sadness and Other Stories ,2005), Cinta Tak Ada Mati (Love Doesn't Die , 2005), Seperti Dendam, Rindu Harus Dibayar Tuntas (Like Missing Revenge Must Be Paid Completely, 2014), serta O (2016). Combining humor with tragedy is a characteristic of Eka's stories.

Lelaki Harimau brings Eka to the list of nominees for the prestigious international literary award, Man Booker International Prize. Despite not being a champion, Eka became the first Indonesian writer and the only one to be on the Man Booker International Prize list. 
Konfrontasi Journal: Culture, Economy and Social Changes, 6 (2) July 2019, 18-30

P-ISSN: 1410-881X (Print)

Herdi Sahrasad, Muhammad Ridwan: A Literary and Cultural Stare of the Red Thread Eka Kurniawan

DOI: -

http://www.konfrontasi.net/index.php/konfrontasi2

Despite being a literary celebrity, Eka feels that nothing has changed in her, except for external changes, which are increasingly busy being invited to a number of events and conducting interviews. The rest, his life remained as usual, taking his daughter, Kidung Kinanti, to school every day, before writing or reading at home. Sometimes he comes to The Reading Room Cafe, Kemang, South Jakarta, and talks with the owner, Richard Oh.

When he studied at PGRI High School, the only school that would accept it without having to repeat the class, for four semesters he managed to maintain the first rank without losing his penchant for truant, he liked to explore the surrounding areas. His favorite places are Segara Anakan swamps (where Nusa Kambangan is located), Cilacap harbor, Japanese heritage caves and start trying to write stories about it all.

Finally he finished his school at PGRI High School and became a legend of the school because he made history as a student who was first accepted into public universities. He was accepted by Gadjah Mada University, Yogyakarta.

On this campus Eka was stunned when she found the library. Throughout college, students majoring in philosophy spend a lot of time in the library. He also met with many literary books. He devoured all the great writers. He read the works of Toni Morrison, Salman Rushdie, Gabriel García Márquez, Leo Tolstoy, Fyodor Dostoyevsky, Melville, and others. Of all the world writers, Pramoedya Ananta Toer, Knut Hamsun, Nikolai Gogol, and Yasunari Kawabata became Eka's favorite writers.

After school he continued his next level at the Faculty of Philosophy at Gadjah Mada University, where he hoped to meet many people who could teach him to write. Several years of studying at Gadjah Mada University Eka Kurniawan finally finished his lecture in 1999 with the title of the thesis "Pramoedya Ananta Toer and Socialist Realism Literature". His thesis entitled "Pramoedya Ananta Toer and Socialist Realism Literature" became the foundation stone for Eka Kurniawan's early football career to begin his career as a writer and comic artist. His thesis was published three times by different publishers and became one of the results of his undergraduate philosophy final assignment. UGU also works on long and powerful literary essays, which are very good with interesting words and discussion. Moreover, the topic of this paper discusses the Pramudya Ananta Toer, one of the Indonesian writers with a very proud array of international achievements.

After the results of his thesis were able to penetrate the world of Indonesian literature, then Eka Kurniawan spread his wings by writing a novel entitled Cantik It Luka with a story line and amazing content. Write down the other side of the woman who is so sad. This novel is finally able to penetrate the international arena. This novel, entitled "Beauty is Wound" (Cantik itu Luka) has been printed in 24 languages, also designed the inaugural World Readers award on March 22 in Hong Kong. Not only that, Eka's second novel entitled "Lelaki Harimau" was in published in 2004 was also included in the Long list of The Man Booker International Prize 2016. "Tiger Men" published by Gramedia Main Library in 2004, translated into 5 languages, and at the 2015 Frankfurt Book Fair (FBF), the name Eka Kurniawan was wrong one highlight in one of the oldest book exhibitions in the world. Furthermore, in 2014 Eka again wrote a novel titled "As Dendam, Rindu Must Be Paid Tuntas" which was published by Gramedia Main Library (Gramedia Pustaka Utama) and this novel was printed also in English. Eka Kurniawan's latest novel titled "O" was published on February 22, 2016 by Gramedia Main Library. The novel is about a monkey who wants to marry Emperor Dangdut. Besides novelists, eka Kurniawan is one of the best short story 
Konfrontasi Journal: Culture, Economy and Social Changes, 6 (2) July 2019, 18-30

P-ISSN: 1410-881X (Print)

Herdi Sahrasad, Muhammad Ridwan: A Literary and Cultural Stare of the Red Thread Eka Kurniawan

DOI: -

http://www.konfrontasi.net/index.php/konfrontasi2

writers. One of the latest short stories of his work is entitled "Broken-Hearted Women Who Returned to Find Love Through Dreams" which was published in Bentang Pustaka in 2015.

In 2006, Eka Kurniwan married a woman who was also a novelist named Ratih Kumala in Solo, Central Java. Ratih is a graduate of the English Literature Faculty of Sebelas Maret University, Surakarta. Aside from being a writer of novels and short stories, Ruth also writes screenplays and works as a drama editor, on a private television. At present, Eka Kurniwan and Ratih Kumala live in Jakarta with their daughter named Kidung Kinanti Kurniawan.

On the sidelines of writing books, he continued his life by becoming a short story writer, journalist, and writing scripts for television films. All the work he did was not far from his love for the world of writing.

In the novel, the personality dynamics of each character include complex oedipus, narcissism, castration, fantasy, dreams, and reflection of mythology. Strange things related to the sexuality of the five figures, were able to be answered by the psychoanalytic approach. This novel is a work that is most talked about by critics, students, the public and general interest in literature.

Eka's second novel titled "Man of the Tiger" which was published in 2004 tells of a family that is "disabled", a husband and wife named Komar and Nuraeni along with 3 sons.

The Komar family is not disabled because the physical is not complete or there is a mental disorder. Every member does deviant things that are not naturally in a normal family.

The central figure is Margio, one of Komar-Nuraeni's children who killed his mother's affair named Anwar Sadat. He also likes to do other harsh actions. But when asked what made him do cruel things, Margio always replied, "This is the work of a tiger in me."

Reading the "Man of the Tiger" to completion will give you an important lesson, that the family is indeed the first school for anyone. Margio grew up to be like that because his father taught violence first. Then all family members are affected, starting to do their own deviant versions.

The next novel 'Seperti Rindu Dendam Harus Dibayar Tuntas', a poetic title given to the 3rd novel Eka Kurniawan.

The novel "'Seperti Rindu Dendam Harus Dibayar Tuntas'" is not merely about love and classical romanticism. It is precisely every page of this novel that contains vulgar words, with striking wild writing styles. Ajo Kawir, the main character in this novel, faces a complicated problem that began when he was little. His genitals can't "stand up" until he is an adult and even become a thug. Seeing naked women arouse the passion of Ajo Kawir, but still the genitals don't have an erection.

This problem began when Ajo was a child. He was caught peeking when 2 police officers raped a crazy woman. Ajo was then dragged in and forced to watch everything from a very close distance. Since then his cock refused to stand, there were bad memories of sexual behavior that imprinted in the mind of Ajo Kawir.

Does this novel focus only on sexuality? Finish until the final page, so you will be amazed by the message that Eka tried to paste in her work. At the end of the story, Ajo Kawir's genitals can tighten again even when he doesn't care about his condition.

Novel " $\mathrm{O}$ " is the popular 4th Eka novel. Yes, the title is indeed just one letter as simple as the cover with a monkey picture. The synopsis listed is only one sentence, "About a monkey who wants to marry the dangdut emperor". 
Konfrontasi Journal: Culture, Economy and Social Changes, 6 (2) July 2019, 18-30

P-ISSN: 1410-881X (Print)

Herdi Sahrasad, Muhammad Ridwan: A Literary and Cultural Stare of the Red Thread Eka Kurniawan

DOI: -

http://www.konfrontasi.net/index.php/konfrontasi2

Reading the title and synopsis certainly makes you wonder, what does this novel want? On the first page we will be greeted with the phrase "It's not easy to be human," said O, a monkey in the Rawa Kalong area. The herd of monkeys in Rawa Kalong believe in the legend about Armo Gundul, a monkey who managed to transform himself into a human. Since then several other monkeys dreamed the same thing, because they thought life would be better if they were human.

But the practice is not that easy, the struggle to be human is complicated and challenging. Only a monkey who does not give up, Entang Kosasih, whose name is O's lover. He then disappears after successfully passing a number of obstacles, and reportedly has become the dangdut emperor in the human world.

O wants to chase his lover, so he must be ready to go through heavy obstacles to become human. Until here, what moral message did you catch? Actually it's about love. Can't be denied, only love can move someone to act. Do anything for something or figure he loves. The problem is, sometimes we don't know whether we love good or bad things.

Then "Scribble Scratch on the Toilet" is a collection of short stories by Eka Kurniawan which contain 12 short stories. Compared to the novel, Eka's short stories are easier to read but still a condition of meaning.

Some of the stories in this book contain fresh humor, which makes you laugh while thinking that life is indeed nice to laugh at. One of the short stories was made into the title of the book, namely "Corat Scratch d Toilet".

Departing from a simple idea, many people suddenly flood ideas while inside the toilet. Like the toilet users that Eka told me in 1999. While defecating, they filled the wall with scribbles about criticism of the government, the restlessness of life and the chaos of the country.

Then aa 'Broken Woman Who Returns to Find Love Through Mimpi', a collection of short stories. Love-themed writings are always successful in attracting readers. Moreover, the title of Eka's one short story collection, "Women Broken Hearts that Re-Find Love Through Dreams".

About a woman named Maya, left behind by her lover just the day before their wedding day was held. Painful, huh? But Maya is not millenials that can be as easy as it devotes turmoil on social media. He chose to sleep, leaving behind a moment of painful real world.

In his dream, Maya saw a shirtless man running around Pangandaran beach with a dog. Not only once or twice, Maya dreams of it almost every day. Until finally he ventured to leave for Pangandaran, feeling that this dream was a good sign that would treat his wound. Eka's works were written with perseverance and concentration which took a long time. Eka is not a writer who easily writes smoothly, smoothly and flowingly, because her imagination and reflection are often wild, unpredictable and sometimes fantastic in style.

When writing literature, Eka sometimes could finish it for days when the mouth was dry gray, his hands were already tired and the eyes were already dull.

When he graduated from college, Eka had become a journalist in Pantau magazine for one year until he finally left because he got a funding grant to write his novel, Cantik Itu Luka. The novel was written by Eka starting in the 2000s. Eka, who does not have a job but has enough money, writes day and night every day, until two years later the novel was published.

Eka Kurniawan once complained positively in his introduction in an anthology of student short stories. According to him, the most tedious task was when he became a judge of 
Konfrontasi Journal: Culture, Economy and Social Changes, 6 (2) July 2019, 18-30

P-ISSN: 1410-881X (Print)

Herdi Sahrasad, Muhammad Ridwan: A Literary and Cultural Stare of the Red Thread Eka Kurniawan

DOI: -

http://www.konfrontasi.net/index.php/konfrontasi2

student short stories. His complaint is positive, if it is digested as a white criticism, on one side Eka is served mostly dry, boring, boring words with mediocre themes and tedious presentations that are typical of beginner writer students.

On the other hand, as a jury who commits him 'requires' his eyes travel from the first word of the first paragraph to the last word in the last paragraph of each work. He must read all the sentences from each boring work without showing boredom. The anthology of the short story published by the University Hall Student Press Institute was the result of a student short story competition.

At that time Eka Kurniawan was not well-known. He just produced a few books. One of them is his thesis which was published as Pramoedya Ananta Toer's book and Socialist Realism Literature. This is phenomenal because in Indonesia it is rare for a thesis to morph into a book. It shows the quality of the thesis and confirms the quality of the owner of the thesis.

Later, a few years later, Eka Kurniawan had shot to occupy the famous orbits properly. One of them was through the Beautiful novel Luka, which had previously been rejected by many publishers. It is said that because it was too thick, and (perhaps) because at that time the name Eka Kurniawan was not yet heard. The publisher calculates capital in response to the novel as thick as a sofa cushion by a writer who is not as classy as Pramoedya. Although he was rejected he was not sad. "I don't really care about that problem, and at that time I still had enough confidence in young people that sooner or later I would find one way to publish it."

But that is the process of one's journey, all beautiful in time, still consistently creative process, fruitful patience: the inaugural novel was published by Jendela and the Yogyakarta Academy of Culture in 2002, then by Gramedia Main Library in 2004.

After being sad, the rejection of the Beauty is A Wound also made Eka sad, a few years later. "Finally I met with an editor who had rejected the novel (his name and signature were written on the small note of refusal), and he frankly said I read my novel and refused it, one of the reasons: the novel did not fit his criteria / preferences about a good literary novel.',

According to him, a good literary novel should be like Mangunwijaya's novels, Kuntowijoyo, Ahmad Tohari. Of course I then read some of their works, and that's when I felt very sad. I am sad because I know exactly: 1) I do not want to write novels like them, 2) if the size of literature (Indonesia) is good measured by their works, I feel I have no place on a literary map and most likely I do not want to be a writer "

Now the editor may regret his heart a little hurt, because the Beautiful Luka was awarded the World Reader's Award on March 22, 2016 in Hong Kong. The flag of Eka Kurniawan is getting more and more brilliant, another novel Heroes of the Tiger made it into the 13 best fiction novel nominees of the version of The Man Booker International Prize 2016.

Both novels have been translated into various foreign languages. He followed in the footsteps of the idol Pramoedya Ananta Toer whose works have been translated since the 60s to the present. Eka really admired and influenced the figure of Pramoedya. Even Benedict Anderson stated that half a century after Pramoedya had been born his successor.

A number of years ago, in a brief conversation on the terrace of a publishing house in Yogyakarta, during the day, Eka Kurniawan said, it was more like using a typewriter manually than a computer. Because the sound of the knock-on-tap beat produced becomes magical music accompanied by imagination that jumps on the mind. No tik tuk is not present when 
Konfrontasi Journal: Culture, Economy and Social Changes, 6 (2) July 2019, 18-30

P-ISSN: 1410-881X (Print)

Herdi Sahrasad, Muhammad Ridwan: A Literary and Cultural Stare of the Red Thread Eka Kurniawan

DOI: -

http://www.konfrontasi.net/index.php/konfrontasi2

pressing the computer keyboard. I do not know whether Eka Kurniawan is now still using a typewriter typewriter in producing masterpieces.

In the same afternoon, Eka Kurniawan with a joking tone with his distinctive smile replied, "That's what I was asking about you." The answer to my question that protested, "Why after becoming a book, the novel Cantik Itu Luka is somewhat different from the draft before publication which was dissected in the court of work at INSIST? "But Eka continued the answer by referring to an foreign poet whom I forgot his name, that the poet uncovered his poetry up to 90 times, only became poetry. Novels can also be dismantled and even very different from the initial script. Eka explained kindly. Eka is indeed a friendly person.

Beautiful That Luka has indeed been dissected in activities designed like a court. The owner of the script like a defendant in the court must be willing to be bombarded with criticism and input to the work. Of course the aim is to make the work more powerful, and if there are still weaknesses it can be corrected, so that it is truly great when published as a book.

Eka Kurniawan may have flown away from society, and that is inseparable from INSIST (the Indonesian Society for Social Transformation) who gave it a wing. INSIST led by activist Mansur Fakih $\mathrm{PhD}$, who at that time was headquartered in the Blimbingsari area of Yogyakarta presented a community that gave space and providing 'organic fertilizer' for young writers to thrive, including Puthut EA and Astrid Reza.

Eka is aware of the existence of a community, association, and 'we' are important. In his blog Eka Kurniawan said, "I said that, because the manifesto was never written. Also because the manifesto can be added to our heart's content. But more or less the manifesto reads:

1) We want to be a writer, if no one publishes, we will publish it ourselves. We learn how to produce books, how to sell them. Even learning to navigate and design covers. 2) If large media does not accept our work, we will create our own media. Yes, even though it's small. Puth made On / Off, before if there was someone who wanted to look for it, he was the only person behind the Magic "journal". Ugo and several of his friends published the Conblock. 3) No literary community accepts us, we will create our own community.

We made it. Some are short-lived, some are very short-lived. The important thing is we make it to support ourselves. We always believe the community should be built to support its members, and not vice versa. Like the state is for the people, and not the other way around. 4) If there are no critics who care about our work, or insult, we will become critics for the work of our own friends, "said Eka's manifesto and the young writers.

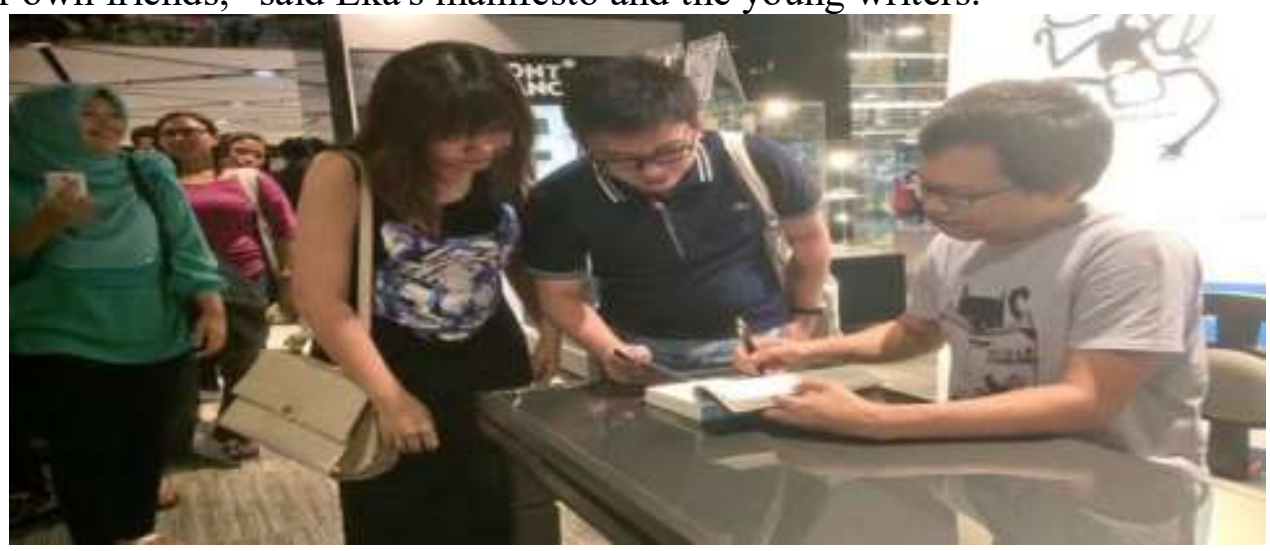

Eka Kurniawan during the $\mathrm{O}$ book launch, in Central Park, Jakarta. (Istimewa)

Ben, Pram, Eka and Realism of Socialist 
Konfrontasi Journal: Culture, Economy and Social Changes, 6 (2) July 2019, 18-30

P-ISSN: 1410-881X (Print)

Herdi Sahrasad, Muhammad Ridwan: A Literary and Cultural Stare of the Red Thread Eka Kurniawan

DOI: -

http://www.konfrontasi.net/index.php/konfrontasi2

\section{Conclusion}

The language of Eka in Beauty, an elegant wound, and the wealth of his imagination provided excitement, like joy when he saw the snow falling for the first time. Ben Anderson even mentioned Eka as Pramoedya's replacement. He also mentioned Eka as the novel writer and the most original short story in Indonesia. Eka claimed to imitate Pram's discipline in making story details. Eka's comment? "I'm still far from Pram," Eka said in response to her comparison with Pramoedya. But it was precisely there that was the challenge for Eka to continue working as Ben Anderson and Pramudya had hoped for him.

\section{References}

Andre Vltchek and Rossie Indira, Saya Terbakar Amarah Sendirian! Pramoedya Ananta Toer dalam Perbincangan dengan Andre Vltchek \& Rossie Indira, Penerbit: KPG (Kepustakaan Populer Gramedia) Cetakan : Pertama, Januari 2006

Arif Novianto, Jejak Langkah Indonesia Hadir di Bumi Manusia: Pramoedya \& Embrio Kebangsaan, makalah, disampaikan dalam diskusi MAP Corner-Klub MKP UGM, Pramoedya \& Jejak Langkah Indonesia Sebagai Bangsa (Yogyakarta, 19 September 2017).

Ahmad Naufal Azizi, Review Roman : Bumi Manusia Karya Pramoedya Ananta Toer, makalah, Jurusan Politik dan Pemerintahan Fakultas Ilmu Sosial dan Ilmu Politik Universitas Gadjah Mada, 2015

Aqsha Al Akbar, Review: Bumi Manusia, makalah, Malang, 10 Februari 2014

Benedict R. O'G. Anderson, Exit Suharto, Obituary for a Mediocre Tyrant, New Left Review Mar-Apr 2008 pp.27-59

Eka Kurniawan, Cantik itu Luka. Jakarta: Gramedia Pustaka Utama.2004, p.96, p.165, p. 252 Pramoedya Ananta Toer, Realisme sosialis dan Sastra Indonesia, Lentera Dipantara 2007.

Pramoedya Ananta Toer, Bumi Manusia, Penerbit Hasta Mitra,1980.

Terry Eagleton, Teori Sastra : Sebuah Pengantar Komprehensif. Yogyakarta: Jalasutra, 2006

Wiyatmi, Representasi Peran dan Relasi Gender dalam Novel "'Cantik Itu Luka" karyua Eka

Kurniawan dan Novel 'Nayla'" karya Djenar Maesa Ayu, jurnal Litera, volume 8 Nomer 1 April 2009, pp 82-92

Yeni Yulianti, Psikoanalisis dalam 'Cantik Itu Luka' karya Eka Kurniawan, jurnal Sintesis, Vol.5 Nomer 2, Oktober 2007 pp 136-152

Majalah/Koran:

Luqman Abdul Hakim, Realisme Sosialis di Indonesia: Pergulatan Pemikiran Seniman dan Sastrawan dalam Situasi Sosial Politik 1950-1965, esai, koran Berita Nasional, 11 September 2017.

Fajar W. Hermawan, Yandi Mohammad, Heru Triyono dan Muammar Fikrie, Eka Kurniawan: Menjadi the next Pram adalah hal biasa, https://beritagar.id/artikel/bincang/wawancaranovelis-eka-kurniawan-menjadi-the-next-pram-adalah-hal-biasa diakses 10/7/2019 pukul 22.00

Made Supriatma, 'Ben Anderson, Seorang Ilmuwan Progresif' https://indoprogress.com/2015/12/ben-anderson-seorang-ilmuwan-progresif/ diakses $12 / 6 / 2019$, pukul 23.02 
Konfrontasi Journal: Culture, Economy and Social Changes, 6 (2) July 2019, 18-30

P-ISSN: 1410-881X (Print)

Herdi Sahrasad, Muhammad Ridwan: A Literary and Cultural Stare of the Red Thread Eka

Kurniawan

DOI: -

http://www.konfrontasi.net/index.php/konfrontasi2

John Roosa, Obituari: Benedict Anderson (1936-2015), diterjemahkan oleh M. Zaki Hussein dari judul asli Benedict Anderson (1936-2015), https://indoprogress.com/2016/08/obituari-benedict-anderson-1936-2015/

Wa Ode Wulan Ratna, Eka Kurniawan: Keliling Eropa Bersama Si Cantik, https://jurnalruang.com/read/1510153999-eka-kurniawan-keliling-eropabersama-sicantik

Wawancara Eka Kurniawan: Aku Berkali-kali Mencoba Berhenti Menulis https : //mojok.co/mih/liputan/wawancara-eka-kurniawan/

Eka Kurnaiwan Antara Pengaruh Pram \& Enny Arrow, https://x.detik.com/detail/metropop/20160505/Kebengalan-Kebengalan-Eka-Kurniawan/ 